\title{
Hubungan Kebiasaan Merokok dengan Angka Kejadian Stomatitis Nikotina pada Nelayan Puger Jember
}

(Correlation Between Smoking Habit and Incident of Nicotine Stomatitis in Fisherman at Puger Jember)

Intan Maulia Cahya Hutami ${ }^{*}$, Elyda Akhya Afida Misrohmasari², Leni Rokhma Dewi ${ }^{3}$, Sri Hernawati ${ }^{3}$, Kiswaluyo²

$1^{*}$ Fakultas Kedokteran Gigi, Universitas Jember

2 Bagian IKGM. Fakultas Kedokteran Gigi, Universitas Jember

3 Bagian Penyakit Mulut, Fakultas Kedokteran Gigi, Universitas Jember

\section{Abstrak}

Kebiasaan merokok adalah masalah kesehatan yang banyak ditemukan di masyarakat secara global. Indonesia memiliki jumlah perokok aktif terbesar yaitu mencapai 65 juta orang. Nelayan adalah salah satu pekerjaan di Indonesia yang merupakan perokok aktif dan memiliki proporsi terbesar yaitu mencapai $44.5 \%$ dibandingkan dengan kelompok pekerjaan lainnya. Kebiasaan merokok dapat menyebabkan kondisi patologis pada rongga mulut. Respon terhadap panas yang ditimbulkan oleh pembakaran batang rokok yang diletakkan di dalam rongga mulut dapat menyebabkan inflamasi pada mukosa palatum yang disebut penyakit stomatitis nikotina. Tujuan penelitian untuk mengetahui prevalensi stomatitis nikotina pada nelayan di Desa Puger Kulon dan mengetahui hubungan antara usia, jenis rokok, dan intensitas merokok terhadap terjadinya stomatitis nikotina pada nelayan. Data diperoleh melalui wawancara pada 301 responden. Purposive sampling digunakan dalam penelitian ini. Uji chi-square digunakan untuk melihat hubungan antara usia, jenis rokok, dan intensitas merokok dengan terjadinya stomatitis nikotina. Prevalensi stomatitis nikotina pada nelayan di Desa Puger Kulon sebesar 5,3\% dan usia, jenis rokok, serta intensitas merokok tidak memiliki hubungan yang signifikan terhadap terjadinya penyakit stomatitis nikotina pada nelayan di Desa Puger Kulon, Kecamatan Puger, Kabupaten Jember.

Kata kunci: merokok, nelayan, Puger, dan stomatitis nikotina,

\section{Abstract}

Smoking habit is a health problem that is found globally. Indonesia has the largest number of active smokers, reaching 65 million people. Fisherman is one of the occupation in Indonesia which have the largest proportion of active smokers, almost 44,5\% compared to other occupation. Smoking habit triggers pathological conditions in the oral cavity. Smoking cause an inflammation of the palatal mucosa named nicotine stomatitis. The purpose was to determine the prevalence of nicotine stomatitis in fisherman at Puger Kulon and to find out the correlation between age, type of cigarette, the intensity of smoking and the incident of nicotine stomatitis in fisherman. Data were collected by interview with 301 respondents. Purposive sampling was used in this study. The chisquare test was used to examine the correlation between age, type of cigarette and the intensity of smoking with the incident of nicotine stomatitis. The prevalence of nicotine stomatitis in fisherman at Puger Kulon Village is $5.3 \%$ and age, type of cigarette, and intensity of smoking did not have a significant correlation to the incident of nicotine stomatitis in fisherman at Puger Kulon Village Puger District Jember Regency.

Keywords: Fisherman, Nicotine Stomatitis, Puger, Smoking

Korespondensi (correspondence) : Intan Maulia Cahya Hutami. Fakultas Kedokteran Gigi. Jalan Kalimantan No. 37, Kampus Tegalboto, Jember, Jawa Timur, 68121. intansitepu@gmail.com

Kebiasaan merokok adalah kebiasaan yang termasuk dalam masalah kesehatan yang banyak ditemukan di masyarakat secara global. Indonesia memiliki jumlah perokok aktif terbesar yaitu mencapai 65 juta orang atau sekitar $34.7 \%$ !. Kebiasaan merokok dapat menyebabkan kondisi patologis pada rongga mulut. Respon terhadap panas yang ditimbulkan oleh pembakaran batang rokok yang diletakkan di dalam rongga mulut dapat menyebabkan inflamasi pada mukosa palatum, dikarenakan mukosa palatum adalah daerah pertama yang akan terpajan oleh panas dari rokok. Inflamasi pada kelenjar saliva minor di mukosa palatum ini dinamakan penyakit stomatitis nikotina ${ }^{2}$.

Stomatitis nikotina yang sering disebut smoker's palate, leukokeratosis nikotina palati, atau stomatitis palatini merupakan lesi yang berada di mukosa rongga mulut khususnya pada mukosa palatina. Stomatitis nikotina dipengaruhi dapat dipengaruhi oleh usia, intensitas merokok, dan jenis rokok. Stomatitis nikotina sering ditemukan pada orang yang merokok menggunakan jenis rokok cerutu dan rokok $\mathrm{pipa}^{2}$. Faktor usia dapat mempengaruhi kondisi patologis pada rongga mulut dimana kebiasaan merokok yang dimiliki oleh seseorang berusia lanjut dimasa lalunya juga dapat menyebabkan berbagai keluhan di rongga mulut akibat menurunnya sistem imun. Penyakit stomatitis nikotina sering ditemukan pada perokok dengan intensitas merokok lebih dari 20 batang $^{3}$.

Perokok aktif di Indonesia banyak ditemukan pada beberapa mata pencaharian. Data RISKESDAS tahun 2013 menunjukkan nelayan adalah salah satu pekerjaan di Indonesia yang merupakan perokok aktif setiap hari dan memiliki proporsi terbesar yaitu mencapai $44.5 \%$ dibandingkan 
dengan kelompok pekerjaan lainnya. Nelayan adalah salah satu mata pencaharian yang terdapat di Kabupaten Jember. Pekerjaan nelayan banyak terdapat di daerah kecamatan Puger khususnya di Desa Puger Kulon karena merupakan daerah pesisir pantai.

Penelitian yang telah dilakukan oleh Mulalinda dkk pada tahun 2015 menunjukkan prevalensi stomatitis nikotina pada nelayan di kecamatan Tuminting, Sulawesi Utara mencapai $68.5 \%^{3}$. Pada penelitian Rajesh dkk pada tahun 2014 di India menunjukkan prevalensi stomatitis nikotina sebesar $7,91 \%$. Perbedaan wilayah, suku, dan ras pada kedua penelitian tersebut dapat mempengaruhi perbedaan angka prevalensi yang didapatkan. Belum ditemukannya penelitian tentang stomatitis nikotina pada masyarakat nelayan di Desa Puger Kulon mendasari penulis untuk melakukan penelitian tentang hubungan kebiasaan merokok dengan kejadian stomatitis nikotina pada nelayan di Desa Puger Kulon, Jember.

\section{METODE PENELITIAN}

Penelitian ini merupakan penelitian observasional analitik dengan pendekatan cross-sectional. Populasi dalam penelitian ini adalah seluruh nelayan yang tinggal di Desa Puger Kulon, yaitu sebesar 1384 orang dengan besar sampel yang digunakan berdasarkan perhitungan rumus adalah 301 sampel. Teknik pengambilan sampel penelitian ini secara purposive sampling. Kriteria sampel yang digunakan adalah kriteria inklusi yaitu; pria yang memiliki kebiasaan merokok rutin, usia $\geq 17$ tahun, bekerja sebagai nelayan, bersedia mengikuti penelitian. Kriteria eksklusi yaitu; pria dengan kebiasaan merokok yang jarang dilakukan, usia < 17 tahun, tidak bersedia mengikuti penelitian, menggunakan full denture pada rahang atas.

Penelitian ini menggunakan data primer yaitu pemeriksaan langsung dan wawancara pada responden. Data primer yang diambil adalah responden dengan stomatitis nikotina, kelompok usia responden, jenis rokok responden, intensitas merokok responden, pendidikan dan suku dari responden. Gambaran klinis stomatitis nikotina berupa mukosa palatal yang berwarna putih atau keabu-abuan dengan batas yang tidak jelas dan terdapat banyak lesi papula dengan bintik merah di tengahnya. Analisis data dilaksanakan untuk mendapatkan angka prevalensi stomatitis nikotina pada nelayan dengan menggunakan rumus, sedangkan untuk mengetahui hubungan antara variabel usia, jenis rokok, dan intensitas merokok dengan angka kejadian stomatitis nikotina digunakan uji statistik hubungan chi-square. Etika penelitian di dapatkan dari Komisi Etik Penelitian Fakultas Kedokteran Gigi, Universitas Jember dengan nomor 126/UN25.8/KEPK/DL/2018. Seluruh responden diberikan surat kesediaan penlitian sebelum pengambilan data, dan identitas responden dijaga kerahasiaannya.

\section{HASIL PENELITIAN}

Total responden pada penelitian ini yaitu sebanyak 301 orang. Responden dibagi menjadi empat kelompok usia yaitu kelompok usia 17-25 tahun, 26-35 tahun, 36-45 tahun, dan 46-55 tahun. Urutan pertama responden yang memiliki jumlah paling banyak adalah kelompok usia 36-45 tahun yaitu sebesar 34,6\% atau sebanyak 104 orang. Selain itu, mayoritas responden terakhir bersekolah di sekolah dasar (SD) yaitu sebanyak 157 orang atau 52,2\%. Mayoritas suku dari responden adalah suku jawa yaitu sebesar $76,4 \%$. Karakteristik dasar responden dapat dilihat pada Tabel 1.

Distribusi responden berdasarkan jenis rokok dan intensitas merokok dapat dilihat pada Tabel 2. Jenis rokok dibagi menjadi tiga jenis yaitu rokok putih, rokok kretek, dan rokok campuran (rokok putih dan rokok kretek). Rokok yang paling banyak digunakan oleh responden adalah rokok putih sebesar $73,4 \%$ atau sebanyak 221 responden. Responden dikelompokkan berdasarkan intensitas merokok. Mayoritas responden menghisap rokok sebanyak $>20$ batang per hari atau biasa disebut perokok berat. Jumlah perokok berat pada penelitian ini adalah 213 orang atau sebesar $70,8 \%$.

Tabel 1. Karakteristik Dasar Responden ( $n=301)$

\begin{tabular}{|c|c|c|c|}
\hline Karakteris & Responden & Jumlah & Presentase (\%) \\
\hline \multirow{4}{*}{ Usia } & $17-25$ & 24 & 8 \\
\hline & $26-35$ & 76 & 25,20 \\
\hline & $36-45$ & 104 & 34,60 \\
\hline & $46-55$ & 97 & 32,20 \\
\hline \multirow{5}{*}{ Pendidikan } & Tidak sekolah & 34 & 11,30 \\
\hline & SD & 157 & 52,20 \\
\hline & SMP & 81 & 26,90 \\
\hline & SMA & 28 & 9,30 \\
\hline & S1 & 1 & 0,30 \\
\hline \multirow{3}{*}{ Suku } & Jawa & 230 & 76,40 \\
\hline & Madura & 69 & 22.90 \\
\hline & Lain-lain & 2 & 0,70 \\
\hline
\end{tabular}


Tabel 2. Distribusi Responden ( $n=301)$

\begin{tabular}{|c|c|c|c|}
\hline \multicolumn{2}{|c|}{ Distribusi Responden } & Jumlah & Presentase (\%) \\
\hline \multirow{3}{*}{ Jenis Rokok } & Rokok Putih & 221 & 73,40 \\
\hline & Rokok Kretek & 34 & 11,30 \\
\hline & Rokok Campuran & 46 & 15,30 \\
\hline \multirow{3}{*}{$\begin{array}{c}\text { Intensitas } \\
\text { Merokok/ } \\
\text { hari }\end{array}$} & $\leq 10$ batang & 13 & 4,30 \\
\hline & 11-20 batang & 75 & 24,90 \\
\hline & > 20 batang & 213 & 70,80 \\
\hline
\end{tabular}

Tabel 3. Distribusi Stomatitis Nikotina pada Responden $(n=301)$

\begin{tabular}{ccc}
\hline Stomatitis Nikotina & Jumlah & Presentase (\%) \\
\hline Ada & 16 & 5,30 \\
Tidak & 285 & 94,70 \\
\hline
\end{tabular}

Tabel 4. Jumlah dan Presentase Penderita Stomatitis Nikotina dari Seluruh Responden Berdasarkan Usia, Jenis Rokok, dan Intensitas Merokok ( $n=301$ )

\begin{tabular}{|c|c|c|c|c|}
\hline \multicolumn{2}{|c|}{ Distribusi Responden } & $\begin{array}{c}\text { Jumlah } \\
\text { Responden }\end{array}$ & $\begin{array}{l}\text { Jumlah Penderita } \\
\text { Stomatitis Nikotina }\end{array}$ & Presentase (\%) \\
\hline \multirow{4}{*}{ Usia } & $17-25$ & 24 & 2 & 8,3 \\
\hline & $26-35$ & 76 & 5 & 6,6 \\
\hline & $36-45$ & 104 & 2 & 1,9 \\
\hline & $46-55$ & 97 & 7 & 7,2 \\
\hline \multirow{3}{*}{ Jenis Rokok } & Rokok Putih & 221 & 11 & 5 \\
\hline & Rokok Kretek & 34 & 3 & 8,8 \\
\hline & Rokok Campuran & 46 & 2 & 4,3 \\
\hline \multirow{3}{*}{$\begin{array}{c}\text { Intensitas } \\
\text { Merokok/ } \\
\text { hari }\end{array}$} & $\leq 10$ batang & 13 & 0 & 0 \\
\hline & $11-20$ batang & 75 & 2 & 2,7 \\
\hline & $>20$ batang & 213 & 14 & 6,6 \\
\hline
\end{tabular}

Presentase penderita stomatitis nikotina dapat dilihat pada Tabel 3. Hasil penelitian menunjukkan sebanyak 16 orang menderita stomatitis nikotina. Prevalensi penderita stomatitis nikotina pada nelayan didapatkan sebesar 5,3\%. Responden dengan stomatitis nikotina dikelompokkan berdasarkan usia, jenis rokok, dan intensitas merokok yang dapat dilihat pada Tabel 4. Responden yang menderita stomatitis nikotina berdasarkan presentase tertinggi terlihat pada kelompok usia 17-25 tahun yang berjumlah 24 orang dengan penderita stomatitis nikotina yang berjumlah 2 orang memiliki presentase sebesar $8,3 \%$, sedangkan pada kelompok usia 36-45 tahun memiliki presentase terkecil yaitu sebesar $1,9 \%$. Perokok kretek yang berjumlah 34 orang dan 3 orang yang menderita stomatitis nikotina memiliki presentase tertinggi yaitu $8,8 \%$. Mayoritas responden dengan stomatitis nikotina merokok sebanyak $>20$ batang per hari. Jumlah responden dengan stomatitis nikotina yang merokok sebanyak $>20$ batang per hari sebanyak 14 orang dengan presentase sebesar $6,6 \%$.

Analisa data yang digunakan dalam penelitian ini adalah uji hubungan chi square. Apabila nilai signifikansi yang dihasilkan dari uji chi square lebih kecil dari 0,05, maka hubungan yang dihasilkan adalah signifikan. Hasil uji hubungan chi square untuk variabel usia didapatkan nilai signifikansi sebesar 0,315. Hasil uji hubungan untuk variabel jenis rokok menunjukkan nilai signifikansi sebesar 0,648. Hasil uji hubungan chi square untuk variabel intensitas merokok didapatkan nilai signifikansi sebesar 0,280. Ketiga hasil tersebut menunjukkan tidak terdapat hubungan yang signifikan antara variabel usia, jenis rokok, dan intensitas merokok dengan angka kejadian stomatitis nikotina.

\section{PEMBAHASAN}

Hasil penelitian di Desa Puger Kulon Kecamatan Puger didapatkan prevalensi terjadinya stomatitis nikotina pada nelayan sebesar 5,3\%. Angka prevalensi ini tidak jauh berbeda dengan penelitian Rajesh dkk tahun 2014 pada populasi Chennai di India yang menunjukkan prevalensi stomatitis nikotina sebesar $7,91 \%$. Penelitian oleh Cade pada tahun 2017 menunjukkan angka prevalensi stomatitis nikotina yang lebih tinggi pada perokok aktif di Arab Saudi sebesar 29,6\%5. Penelitian di Indonesia juga telah dilakukan sebelumnya oleh Mulalinda tahun 2015 di daerah Sulawesi yang menunjukkan angka prevalensi yang lebih besar yaitu $68,5 \%{ }^{3}$.

Variasi angka prevalensi stomatitis nikotina pada beberapa penelitian dapat disebabkan oleh perbedaan tempat dan daerah yang diteliti. Penggambaran terjadinya penyakit dapat dibedakan berdasarkan tempat dan karakteristik seseorang seperti ras dan suku.

Mayoritas suku yang terdapat pada 
penelitian ini adalah suku Jawa, sedangkan penelitian Mulalinda berada di daerah Sulawesi sehingga terdapat perbedaan suku dan juga kebiasaan. Daerah Sulawesi memiliki beberapa acara adat seperti rambu tuka, rambu solo, dan metipu yang menjadikan rokok sebagai syarat dalam perayaan pesta adat sedangkan suku Jawa tidak memiliki acara tersebut, sehingga masyarakat di daerah Sulawesi lebih sering terpapar asap rokok yang dapat menyebabkan angka kejadian penyakit stomatitis nikotina lebih tinggi.

Variabel independen pertama dalam penelitian ini adalah usia. Jumlah responden terbanyak yang menderita stomatitis nikotina terdapat pada kelompok usia 46-55 tahun dikarenakan seiring dengan bertambahnya usia terjadi penurunan fungsi sistem imun dan terjadi peningkatan respon autoimun. Kebiasaan merokok yang dimiliki oleh responden berusia lanjut dimasa lalunya dapat menyebabkan berbagai keluhan di rongga mulut akibat menurunnya sistem imun. Presentase terbesar yang didapatkan jumlah penderita stomatitis nikotina dari seluruh responden adalah pada kelompok usia 17-25 tahun dikarenakan jumlah responden yang berusia 17-25 tahun memiliki jumlah paling sedikit dibandingkan dengan jumlah responden pada kelompok usia lainnya sehingga presentase yang didapatkan menjadi lebih besar dibandingkan dengan kelompok usia lainnya.

Uji hubungan chi square untuk variabel usia didapatkan hasil tidak terdapat hubungan yang signifikan antara variabel usia dengan angka kejadian stomatitis nikotina. Hal ini dapat disebabkan oleh lama merokok. Semakin lama seseorang mengkonsumsi rokok dan tidak menghentikan kebiasaan tersebut maka akan semakin banyak terbentuknya kelainan pada mukosa mulut. Beberapa responden pada penelitian ini yang berumur 36 tahun keatas ada yang sempat berhenti merokok. Beberapa responden berhenti merokok sekitar 3 bulan sampai 2 tahun kemudian melanjutkan kembali kebiasaan merokoknya, sehingga usia tidak dapat menentukan lama merokok dari seseorang. Variabel usia tidak berhubungan secara signifikan pada kejadian stomatitis nikotina.

Variabel independen kedua adalah jenis rokok. Jenis rokok adalah rokok yang diklasifikasikan berdasarkan bahan baku, dimana rokok putih adalah rokok yang hanya berisi daun tembakau dan menggunakan filter, sedangkan rokok kretek berisi daun tembakau, cengkeh, dan tidak menggunakan filter. Mayoritas penderita stomatitis nikotina menghisap rokok putih karena sebagian besar responden dalam penelitian ini memilih menggunakan rokok putih, sehingga angka kejadian penyakit stomatitis nikotina banyak ditemukan pada responden yang menggunakan rokok putih.

Uji hubungan chi square antara variabel jenis rokok dengan angka terjadinya stomatitis nikotina menunjukkan hasil tidak terdapat hubungan yang signifikan antara variabel jenis rokok dengan angka kejadian stomatitis nikotina. Penyakit stomatitis nikotina cenderung disebabkan oleh panas yang dihasilkan dari pembakaran rokok. Panas tersebut langsung mengenai daerah palatum yang dapat menyebabkan inflamasi pada kelenjar saliva minor di daerah palatum. Temperatur yang dihasilkan dari pembakaran rokok sama tingginya yaitu mencapai $650^{\circ} \mathrm{C}^{6}$. Tidak ada hubungan yang signifikan antara jenis rokok dan stomatitis nikotina juga dapat disebabkan karena kandungan yang sama dari kedua jenis rokok tersebut. Kandungan dari rokok yang dapat mempengaruhi terjadinya penyakit stomatitis nikotina adalah nikotin dan tar ${ }^{4}$. Jumlah kandungan nikotin, tar dan $\mathrm{CO}$ yang dihasilkan dari pembakaran rokok kretek dan rokok putih memiliki jumlah yang berbeda. Rokok kretek memiliki kandungan nikotin, tar, dan $\mathrm{CO}$ yang lebih banyak dibandingkan dengan rokok putih. Hal tersebut dapat disebabkan karena rokok kretek tidak memilki filter yang berfungsi untuk mengurangi asap yang keluar dari rokok, sehingga resiko terjadinya stomatitis nikotina lebih tinggi pada pengguna rokok kretek7 .

Variabel selanjutnya adalah intensitas merokok. Intensitas merokok adalah banyaknya rokok yang dihisap oleh seseorang per hari. Penderita stomatitis nikotina yang termasuk perokok berat atau yang merokok $>20$ batang per hari berjumlah 14 orang. Jumlah tersebut adalah jumlah paling banyak diantara jenis perokok yang lainnya. Perokok berat memiliki banyak keluhan pada rongga mulutnya dibandingkan dengan perokok sedang ataupun perokok ringan. Kandungan dan juga panas yang dihasilkan dari pembakaran rokok dapat menimbulkan penyakit yang bervariasi pada rongga mulut salah satunya adalah stomatitis nikotina, sedangkan responden yang menghisap rokok $\leq 10$ batang per hari tidak ada yang menderita stomatitis nikotina dikarenakan paparan panas rokok yang tidak terlalu tinggi pada perokok ringan sehingga tidak sampai menimbulkan iritasi ataupun inflamasi pada daerah palatum ${ }^{3,8}$.

Uji hubungan chi square untuk variabel intensitas merokok didapatkan hasil tidak terdapat hubungan yang signifikan antara variabel intensitas merokok dengan angka kejadian stomatitis nikotina. Hal tersebut disebabkan karena terjadinya penyakit stomatitis nikotina juga dipengaruhi oleh faktor lain yaitu lama merokok. Lama merokok disini berarti lamanya kebiasaan merokok yang dimiliki oleh seseorang, dimana seseorang yang sudah lama memiliki kebiasaan merokok aktif akan lebih sering dan lebih lama terpapar oleh panas pembakaran rokok, sehingga banyaknya rokok yang dikonsumsi dan lama merokok akan saling berhubungan dengan terjadinya stomatitis nikotina.

Kesimpulan dari penelitian ini yaitu 
prevalensi stomatitis nikotina pada nelayan di Desa Puger Kulon sebesar 5,3\%. Jumlah penderita stomatitis nikotina paling banyak terdapat pada usia 46-55 tahun, dengan jenis rokok yang digunakan rokok putih, dan memiliki intensitas merokok lebih dari 20 batang per hari. Akan tetapi, tidak terdapat hubungan yang signifikan antara usia, jenis rokok, dan intensitas merokok terhadap terjadinya penyakit stomatitis nikotina pada nelayan di Desa Puger Kulon, Kecamatan Puger,

Penelitian ini dapat menjadi bahan media promotif preventif mengenai akibat dari kebiasaan merokok. Media prmotif preventiv dapat dilakukan pada masyarakat khususnya komunitas nelayan di Desa Puger Kulon, Kecamatan Puger Kabupaten Jember.

\section{DAFTAR PUSTAKA}

1. Neilis S., I.E. Putri, R. Mahmud. Hubungan kebiasaan merokok dengan status kesehatan jaringan periodontal. Stomatognatic (J.K.G Unej) 2015; 12 (2): 71-74

2. Neville, B. W., D. D. Damm, C. M. Allen, dan J. E. Bouquot. Oral and Maxillofacial Pathology. 4rd. Missouri: Saunders Elsevier. 2015 : 403.

3. Mulalinda, S.L., P.L. Suling, dan C.N. Mintjelungan. Lesi yang diduga stomatitis nikotina pada nelayan yang memiliki kebiasaan merokok.
Pharmacon Jurnal Ilmiah Farmasi - Unsrat 2015;4(4): 90-95.

4. Rajesh, E., K.M.K. Masthan, N.A. Babu, L. Sankari, L. Malathi, dan N. Anitha. Prevalence of nicotina-stomatitis among 320 smokers in Chennai population. Biosciences Biotechnology Research Asia 2014; 11 (2): 701-703.

5. Cade, J. E. 2017. Nicotine Stomatitis. Meharry Medical College School of Dentistry

https://emedicine.medscape.com/articl e/1076183-overview. [Diakses pada 4 Mei 2018].

6. Prabowo, D. M. S., dan Widodo H. B. Nicotine stomatitis in smokers: a case report. Journal of Dentomaxillofacial Science 2018; 3(1): 58-60.

7. Diza, A.M., H.S. Huboyo, dan Z. Muhlisin. 2014. Studi penyisihan emisi CO pada asap rokok kretek filter dan non filter dengan variasi tegangan listrik menggunakan teknologi plasma. Jurnal Teknik Lingkungan 2014; 3(4). 1-8.

8. Siwi, F.A.P., D.H.C. Pangemanan, dan P.N. Gunawan. Prevalensi stomatitis nikotina pada buruh tambang yang memiliki kebiasaan merokok. Jurnal eGigi 2017; 5(1): 58-63. 